\title{
Synthesis, Characterization, and Antimicrobial Studies of N, O Donor Schiff Base Polymeric Complexes
}

\author{
Shubhangi N. Kotkar ${ }^{1}$ and Harjeet D. Juneja ${ }^{2}$ \\ ${ }^{1}$ Government Polytechnic, Gondia, Maharashtra 441601, India \\ ${ }^{2}$ Department of Chemistry, RTMNU, Nagpur, Maharashtra 440033, India \\ Correspondence should be addressed to Shubhangi N. Kotkar; snkotkar21@gmail.com
}

Received 9 May 2013; Revised 1 August 2013; Accepted 1 August 2013

Academic Editor: Antonio Manuel Romerosa-Nievas

Copyright (C) 2013 S. N. Kotkar and H. D. Juneja. This is an open access article distributed under the Creative Commons Attribution License, which permits unrestricted use, distribution, and reproduction in any medium, provided the original work is properly cited.

A series of new polymeric complexes of $\mathrm{Mn}(\mathrm{II}), \mathrm{Co}(\mathrm{II}), \mathrm{Ni}(\mathrm{II}), \mathrm{Cu}(\mathrm{II})$, and $\mathrm{Zn}$ (II) were prepared with a Schiff base ligand derived from condensation of 2,4-dihydroxy acetophenone and p-phenylene diamine and characterized by elemental analysis and IR and NMR spectral data. The antimicrobial activity of the Schiff base and its polymeric complexes have been studied.

\section{Introduction}

Compounds containing imines bases have found extensive applications in organic synthesis [1]; several of these molecules display significant biological activity. In the last decade Schiff base ligands [2-4] have received more attention mainly because of their wide applications in the field of catalysis [5] and due to their antimicrobial [6-8] and antifungal activity [9].

Schiff bases play an important role in inorganic chemistry as they can easily form stable complexes with most transition metal ions $[10,11]$. The development of the field of bioinorganic chemistry has increased the interest in Schiff base complexes, since it has been recognized that many of these complexes may serve as models for biologically important species. Schiff base metal complexes were investigated for fungicidal, fungistatic, bactericidal, and bacteriostatic activities [12-15].

The condensation reaction between 2,4-dihydroxy acetophenone and p-phenylene diamine yields a new compound with mainly two donor sites suitable for the study of ligational behavior which attracted our attention to synthesize Schiff's base which has been used for the preparation of the metal complexes of transition metals such as $\mathrm{Mn}$ (II), $\mathrm{Co}(\mathrm{II}), \mathrm{Ni}(\mathrm{II})$, $\mathrm{Cu}(\mathrm{II})$, and $\mathrm{Zn}(\mathrm{II})[16]$.

In the present work, the structures of synthesized bis-bidentate ligand and its polymeric metal complexes with $\mathrm{Mn}(\mathrm{II}), \mathrm{Co}(\mathrm{II}), \mathrm{Ni}(\mathrm{II}), \mathrm{Cu}(\mathrm{II})$, and $\mathrm{Zn}(\mathrm{II})$ ions have been characterized by various physicochemical techniques, namely, elemental analysis and IR and NMR spectral studies, and were also screened for antibacterial activities against some species of pathogenic bacteria.

\section{Experimental}

2.1. Materials and Methodology. All the chemicals used were of analytical grade. Solvents used were of analytical grade and purified by standard procedures.

2.2. Synthesis of Ligand. Synthesis of ligand was carried out in two steps. The first step involved the preparation of 2,4dihydroxy acetophenone while the second step involved the preparation of ligand.

2.2.1. Synthesis of 2,4-Dihydroxy Acetophenone. Anhydrous $\mathrm{ZnCl}_{2}(70 \mathrm{~g})$ was dissolved in glacial acetic acid $(65 \mathrm{~mL})$ in a $500 \mathrm{~mL}$ beaker. The solution was heated on wire gauge up to $140^{\circ} \mathrm{C}$, and resorcinol $(45 \mathrm{~g})$ was added slowly with constant stirring. The temperature then raised up to $152^{\circ} \mathrm{C}$, and the solution began to boil. It was allowed to stand for $30 \mathrm{~min}$ and diluted with $\mathrm{HCl}(50 \%)$. The resulting orange colored solid was collected, washed with dil. $\mathrm{HCl}(200 \mathrm{~mL})$, and crystallized from water. The yield was found to be $80 \%$, and 
TABLE 1: Analytical and physical data of the compound studied.

\begin{tabular}{lcccccc}
\hline Compound & Colour & Empirical formula & Mol. Wt & C Cal. (found) & H Cal. (found) & N Cal. (found) \\
\hline $\mathrm{L}$ & Orange & $\mathrm{C}_{22} \mathrm{H}_{20} \mathrm{~N}_{2} \mathrm{O}_{4}$ & 376.41 & $70.13(70.15)$ & $5.31(5.35)$ & $7.43(7.39)$ \\
{$[\mathrm{Mn}(\mathrm{II}) \mathrm{L}] 2 \mathrm{H}_{2} \mathrm{O}$} & Brown & $\mathrm{C}_{22} \mathrm{H}_{18} \mathrm{~N}_{2} \mathrm{O}_{4} \mathrm{Mn} \cdot 2 \mathrm{H}_{2} \mathrm{O}$ & 465.34 & $56.73(56.80)$ & $4.72(4.80)$ & $6.01(6.14)$ \\
{$[\mathrm{Co}(\mathrm{II}) \mathrm{L}] 2 \mathrm{H}_{2} \mathrm{O}$} & Bluish black & $\mathrm{C}_{22} \mathrm{H}_{18} \mathrm{~N}_{2} \mathrm{O}_{4} \mathrm{Co} \cdot 2 \mathrm{H}_{2} \mathrm{O}$ & 469.34 & $56.24(56.33)$ & $3.68(3.92)$ & $5.96(5.98)$ \\
{$[\mathrm{Ni}(\mathrm{II}) \mathrm{L}] 2 \mathrm{H}_{2} \mathrm{O}$} & Grey & $\mathrm{C}_{22} \mathrm{H}_{18} \mathrm{~N}_{2} \mathrm{O}_{4} \mathrm{Ni} \cdot 2 \mathrm{H}_{2} \mathrm{O}$ & 469.10 & $56.27(56.40)$ & $4.68(4.99)$ & $5.96(5.99)$ \\
{$[\mathrm{Cu}(\mathrm{II}) \mathrm{L}]$} & Shining black & $\mathrm{C}_{22} \mathrm{H}_{18} \mathrm{~N}_{2} \mathrm{O}_{4} \mathrm{Cu}$ & 437.95 & $60.28(60.35)$ & $4.11(4.20)$ & $6.39(6.46)$ \\
{$[\mathrm{Zn}(\mathrm{II}) \mathrm{L}]$} & Whitish & $\mathrm{C}_{22} \mathrm{H}_{18} \mathrm{~N}_{2} \mathrm{O}_{4} \mathrm{Zn}$ & 439.81 & $60.02(60.08)$ & $4.09(4.16)$ & $6.36(6.39)$ \\
\hline
\end{tabular}

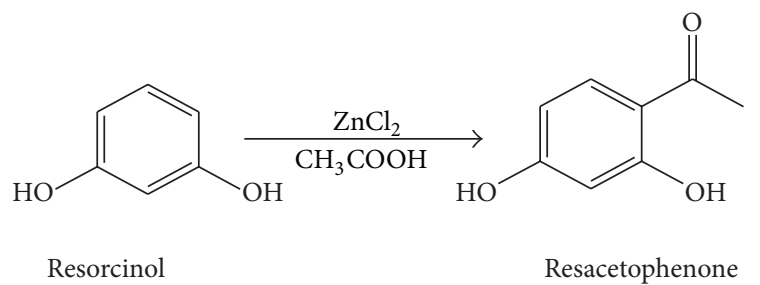

SCHEME 1: Synthesis of resacetophenone.

the melting point was found to be $144^{\circ} \mathrm{C}$. Scheme 1 , represents its synthesis.

2.2.2. Synthesis of $N, N^{\prime}-1,4-P h e n y l e n e$ Bis(2,4-Dihydroxy Acetophenonylidene Imine). 2,4-dihydroxy acetophenone $(0.05 \mathrm{M}, 7.6 \mathrm{~g})$ and $\mathrm{p}$-phenylene diamine $(0.025 \mathrm{M}, 2.7 \mathrm{~g})$ were placed in round bottomed flask in distilled ethanolic medium, and few drops of acetic acid were added as a catalyst. The reaction mixture was refluxed on sand bath for $1 \mathrm{hr}$ and then poured on crushed ice to get yellow-orange crystals of Schiff base ligand $\mathrm{N}^{\prime} \mathrm{N}^{\prime}-1,4$-phenylene bis $(2,4$ dihydroxy acetophenonylidene imine). The precipitated crystals of Schiff base were filtered and recrystallised with aqueous ethanol and dried. The yield was found to be $65 \%$, and the melting point was found to be $125^{\circ} \mathrm{C}$. Scheme 2, represents synthesis of ligand.

2.2.3. Synthesis of Polymeric Complexes. N, $N^{\prime}-1,4$-Phenylene bis(2,4-dihydroxy acetophenonylidene imine) (1 mol) was dissolved in distilled methanol and then added to the metal acetate $(1 \mathrm{~mol})$ in distilled methanol. The reaction mixture was then refluxed on water bath for $2 \mathrm{hr}$ and kept at room temperature for overnight. The precipitated complex was then filtered under suction and washed successively with hot water and methanol to remove unreacted ligand and metal acetate if any present and then dried.

\section{Results and Discussion}

The stoichiometry of the ligand and its polymeric complexes were confirmed by their elemental analysis. The elemental analysis of the ligand and its metal complexes show good support with the proposed structures of the ligand and its complexes and have been reported in Table 1.
3.1. Infrared Spectral Analysis of Schiff Base Ligand. IR spectra of ligand L show an intense band at $3299 \mathrm{~cm}^{-1}$ indicating the presence of phenolic $\mathrm{OH}$ group. This sharp band is absent in the spectra of complexes indicting that the phenolic $\mathrm{OH}$ group is deprotonated and involved in coordination with metal [17].

The ligand shows an intense band due to $v(\mathrm{C}=\mathrm{N})$ of azomethine group at around $1608 \mathrm{~cm}^{-1}$ consistent with the iminic absorption of free Schiff base [18]. The band for phenolic C-O stretching is seen at $1516 \mathrm{~cm}^{-1}$. The medium intense band at $3302-3362 \mathrm{~cm}^{-1}$ which is the characteristic of strong hydrogen bonded $\mathrm{O}-\mathrm{H}$ vibration shows existence of intramolecular $\mathrm{H}$ bonding between phenolic oxygen and azomethine nitrogen [19].

3.2. Infrared Spectral Analysis of Schiff Base Complexes. In all complexes, the band for azomethine group undergoes a shift to lower energy, indicating coordination of azomethine nitrogen with metal ion $[20,21]$. This fact is further supported by appearance of some new bands $\nu(\mathrm{M}-\mathrm{N})$ at $630-667 \mathrm{~cm}^{-1}$ and (M-O) at $410-491 \mathrm{~cm}^{-1}$ in the spectra of complexes [22]. In the complex broad band from 3200 to $3600 \mathrm{~cm}^{-1}$ may be assigned to presence of lattice water. In addition to above bands, the IR bands due to phenyl ring systems between 1520 and $1566 \mathrm{~cm}^{-1}$ which are almost unaffected in the complex have been assigned to aromatic $v(\mathrm{C}=\mathrm{C})$. In all complexes the band for phenolic $(\mathrm{C}-\mathrm{O})$ stretching shows a marked shift of $17-25 \mathrm{~cm}^{-1}$ to higher wave number due to the $\mathrm{C}-\mathrm{O}-\mathrm{M}$ bond formation [23]. The band for intramolecular $\mathrm{H}$ bonding is absent in complexes indicating deprotonation of phenolic -OH group and coordination with metal [24]. Bands at 745$780 \mathrm{~cm}^{-1}$ may attribute to rocking and wagging modes of the coordinated water. This band is absent in the spectra of $\mathrm{CuL}$ and $\mathrm{ZnL}$ indicating absence of coordinated water.

It is concluded from the significant shift of free ligand $\nu(\mathrm{C}=\mathrm{N})$ to lower wave number side, increased wave number for phenolic $v(\mathrm{C}-\mathrm{O})$ stretching band in complexes, that bonding of the ligand to metal ion is through phenolic oxygen and azomethine nitrogen. The data of IR is tabulated in Table 2 .

3.3. 1H NMR Analysis of Ligand and Its Polymeric Complexes. $1 \mathrm{H}$ NMR spectra of ligand at $400 \mathrm{MHz}$ in DMSO exhibit a singlet at $\delta=12.6 \mathrm{ppm}$ for phenolic $-\mathrm{OH}$ and multiplets in the aromatic region $\delta=6.3$ to $7.5 \mathrm{ppm}$, corresponding to 


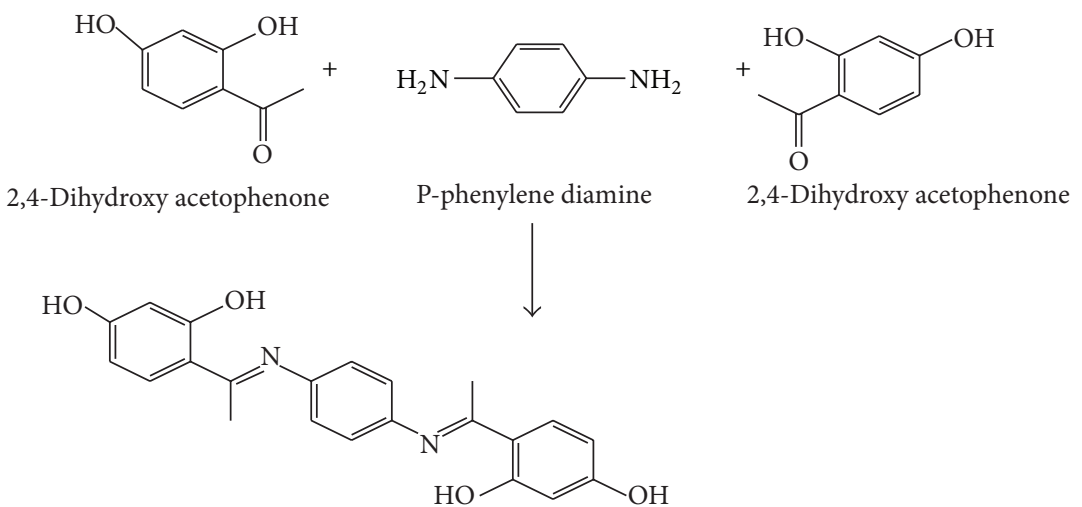

$\mathrm{N}, \mathrm{N}^{\prime}$-1,4-phenylene bis(2,4-dihydroxy acetophenonylidene imine)

SCHEME 2

TABLE 2: Infrared absorption frequencies $\left(\mathrm{cm}^{-1}\right)$ of ligand and its polymeric complexes.

\begin{tabular}{|c|c|c|c|c|c|c|}
\hline S. number & $\begin{array}{l}\text { Compound } \\
\text { code }\end{array}$ & $\begin{array}{c}v \\
(\mathrm{Ar}-\mathrm{OH})\end{array}$ & $\begin{array}{c}v \\
(\mathrm{C}=\mathrm{N})\end{array}$ & $\begin{array}{c}v \\
(\mathrm{M}-\mathrm{N})\end{array}$ & $\begin{array}{c}v \\
(\mathrm{M}-\mathrm{O})\end{array}$ & $\begin{array}{c}v \\
(\mathrm{C}-\mathrm{O})\end{array}$ \\
\hline 1 & $\mathrm{~L}$ & $\begin{array}{l}3302, \\
3362\end{array}$ & 1608 & - & - & 1516 \\
\hline 2 & $\mathrm{MnL}$ & - & 1605 & 630 & 410 & 1560 \\
\hline 3 & $\mathrm{CoL}$ & - & 1590 & 565 & 412 & 1520 \\
\hline 4 & $\mathrm{NiL}$ & - & 1585 & 667 & 428 & 1566 \\
\hline 5 & $\mathrm{CuL}$ & - & 1604 & 650 & 422 & 1532 \\
\hline 6 & $\mathrm{ZnL}$ & - & 1603 & 667 & 491 & 1522 \\
\hline
\end{tabular}

benzene rings. The NMR signal at $\delta=2.5 \mathrm{ppm}$ as a sharp and singlet peak is due to $-\mathrm{CH}_{3}$ proton [25].

$1 \mathrm{H}$ NMR spectra of complexes at $400 \mathrm{MHz}$ in DMSO show no peak corresponding to the presence of phenolic $-\mathrm{OH}$, thus indicating removal of hydrogen and coordination of metal to ligand through phenolic oxygen. Peaks corresponding to benzene rings are also present in spectra of complexes without any change. Retention of peaks in aromatic region without any formal change indicates the preservation of the formal structure of ligand without any deformation. The structure of polymeric compounds has been shown in Figure 1.

3.4. Antimicrobial Activity of Ligand and Its Polymeric Complexes. Synthesized Schiff bases and their corresponding mixed ligand metal complexes were screened against $E$. coli, S. aureus, B. subtilis, and P. aeruginosa to assess their potential as antimicrobial agent by well-diffusion method also called as agar ditch method. The zones of inhibition based upon zone size were measured. The measured zones of inhibition against the growth of various microorganisms have been listed in Table 3.

From Table 3 it has been found that all complexes show greater antibacterial activity than that of ligand [26]. CuL
TABLE 3: Minimum inhibitory zones for ligand and complexes.

\begin{tabular}{|c|c|c|c|c|c|}
\hline \multirow{2}{*}{ Sample } & \multirow{2}{*}{ Conc. $(\mu \mathrm{g})$} & \multicolumn{4}{|c|}{ Zone of inhibition in mm against } \\
\hline & & S. aureus & E. coli & B. subtilis & P. aeruginosa \\
\hline \multirow{4}{*}{$\mathrm{L}$} & 0.25 & 12 & 11 & 10 & 11 \\
\hline & 0.5 & 14 & 12 & 12 & 13 \\
\hline & 0.75 & 15 & 13 & 15 & 15 \\
\hline & 1.0 & 16 & 15 & 20 & 18 \\
\hline \multirow{4}{*}{$\mathrm{MnL}$} & 0.25 & 19 & 19 & 22 & 18 \\
\hline & 0.5 & 23 & 21 & 25 & 22 \\
\hline & 0.75 & 25 & 24 & 27 & 26 \\
\hline & 1.0 & 28 & 25 & 30 & 31 \\
\hline \multirow{4}{*}{$\mathrm{CoL}$} & 0.25 & 14 & - & 12 & 13 \\
\hline & 0.5 & 17 & - & 14 & 21 \\
\hline & 0.75 & 19 & 15 & 17 & 25 \\
\hline & 1.0 & 22 & 20 & 19 & 27 \\
\hline \multirow{4}{*}{$\mathrm{NiL}$} & 0.25 & 12 & 19 & 12 & 16 \\
\hline & 0.5 & 15 & 21 & 16 & 21 \\
\hline & 0.75 & 18 & 23 & 21 & 23 \\
\hline & 1.0 & 20 & 24 & 24 & 26 \\
\hline \multirow{4}{*}{$\mathrm{CuL}$} & 0.25 & 14 & 20 & 14 & 18 \\
\hline & 0.5 & 16 & 23 & 17 & 20 \\
\hline & 0.75 & 19 & 25 & 19 & 22 \\
\hline & 1.0 & 22 & 27 & 24 & 24 \\
\hline \multirow{4}{*}{$\mathrm{ZnL}$} & 0.25 & 13 & 11 & 23 & 11 \\
\hline & 0.5 & 16 & 12 & 27 & 22 \\
\hline & 0.75 & - & 14 & 31 & 33 \\
\hline & 1.0 & 25 & 17 & 36 & 33 \\
\hline
\end{tabular}

and MnL show very good results against all bacterial strains. Furthermore ZnL shows very good antibacterial activity against B. subtilis. 


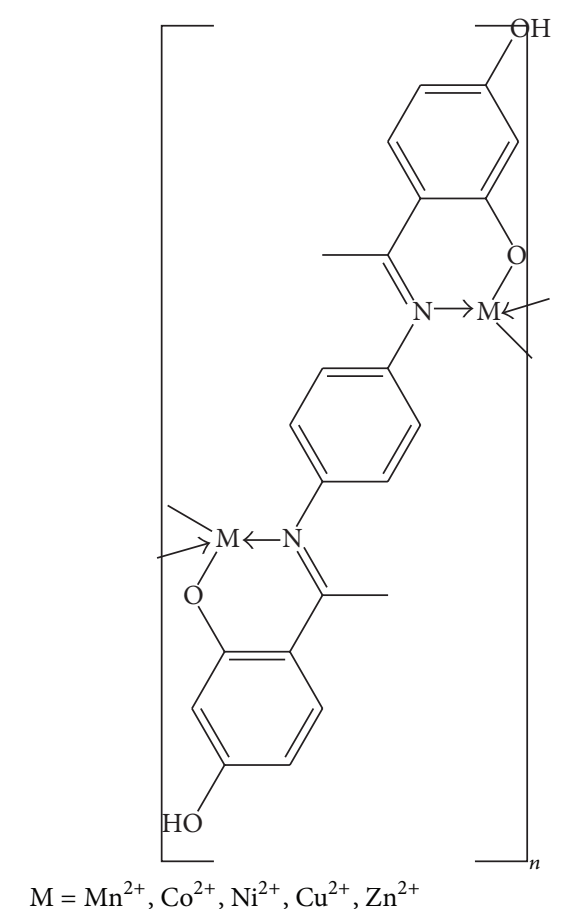

FIGURE 1: Structure of the polymeric compounds.

\section{Conclusion}

From the characterization of ligand and complexes using $\mathrm{CHN}$ analysis, IR and NMR structures of ligand and complexes were proposed. Measurements of inhibition zones of ligand and complexes at different concentrations show that all complexes have enhanced bactericidal activity more than ligand.

\section{References}

[1] A. S. Shakeel, N. V. Kalyane, S. R. Karjgi, and M. L. Ahmed, "Synthesis and antibacterial activity of new Schiff's bases," International Journal of Pharmacy and Life Sciences, no. 5, pp. 246-249, 2010.

[2] R. Johari, G. Kumar, and S. Singh, "Synthesis and antibacterial activity of M (II) Schiff base complex," Journal of the Indian Council of Chemists, vol. 26, pp. 23-27, 2009.

[3] J. H. Pandya and M. K. Shah, "Synthesis and antimicrobial properties of transition metal complexes of novel Schiff base ligand derived from 5-bromosalicyldehyde," Journal of the Indian Council of Chemists, vol. 26, no. 2, pp. 109-112, 2009.

[4] S. Varghese and M. K. Muraleedharan Nair, "Spectroscopic and antimicrobial studies of some 2-hydroxybenzilidene-3aminophenol complexes," Research Journal of Pharmaceutical, Biological and Chemical Sciences, vol. 1, no. 2, pp. 347-353, 2010.

[5] S. Kumar, D. N. Dhar, and P. N. Saxena, "Applications of metal complexes of Schiff bases-a review," Journal of Scientific and Industrial Research, vol. 68, no. 3, pp. 181-187, 2009.

[6] F. M. Morad, M. M. E. L. Ajaily, and S. Ben-Gweirif, "Preparation, physical characterization and antibacterial activity of $\mathrm{Ni}$ (II) Schiff base complex," Journal of Science and Its Applications, vol. 1, pp. 72-78, 2007.
[7] P. Singh and R. K. S. Dhakarey, "Synthesis, characterization and antimicrobial studies of metal complexes with Schiff bases derived from 2-thienyl glyoxal," Rasayan Journal of Chemistry, vol. 2, no. 4, pp. 869-874, 2009.

[8] J. Salimon, N. Salih, E. Yousif, A. Hameed, and H. Ibraheem, "Synthesis, characterization and biological activity of Schiff bases of 2, 5-dimercapto-1,3,4-thiadiazole," Australian Journal of Basic and Applied Sciences, vol. 4, no. 7, pp. 2016-2021, 2010.

[9] K. S. S. Lamani, O. Kotresh, M. A. Phaniband, and J. C. Kadakol, "Synthesis, characterization and antimicrobial properties of Schiff bases derived from condensation of 8-formyl-7-hydroxy4-methylcoumarin and substituted triazole derivatives," $E$ Journal of Chemistry, vol. 6, supplement 1, pp. S239-S246, 2009.

[10] A. M. Hamil, K. M. Khalifa, A. Al-Houni, and M. M. El-Ajaily, "Synthesis, spectroscopic investigation and antiactivity activity of Schiff base complexes of cobalt (II) and copper (II) ions," Rasayan Journal of Chemistry, vol. 2, no. 2, pp. 261-266, 2009.

[11] A. P. Mishra and N. Sharma, "Synthesis, characterization, Xray and thermal studies of some Schiff base metal complexes," Journal of the Indian Council of Chemists, vol. 26, pp. 125-129, 2009.

[12] T. Rosu, S. Pasculescu, V. Lazar, C. Chifiriuc, and R. Cernat, "Copper(II) complexes with ligands derived from 4-amino-2,3dimethyl-1-phenyl-3-pyrazolin-5-one: synthesis and biological activity," Molecules, vol. 11, no. 11, pp. 904-914, 2006.

[13] N. S. Gwaram, H. M. Ali, M. A. Abdulla et al., "Antibacterial evaluation of some Schiff bases derived from 2-acetylpyridine and their metal complexes," Molecules, vol. 17, no. 5, pp. 59525971, 2012.

[14] K. T. Joshi, A. M. Pancholi, K. S. Pandya, and A. S. Thakar, "Synthesis, characterization and antibacterial activity of novel Schiff base derived from 4-acetyl-3-methyl-1-(4'-Methyl-Phenyl)-2Pyrazolin-5-one and its transition metal complexes," International Journal of Research in Chemistry and Environment, vol. 1, no. 2, pp. 263-269, 2011.

[15] A. P. Mishra, R. Mishra, R. Jain, and S. Gupta, "Synthesis of new $\mathrm{VO}(\mathrm{II}), \mathrm{Co}(\mathrm{II}), \mathrm{Ni}(\mathrm{II})$ and $\mathrm{Cu}(\mathrm{II})$ complexes with isatin-3- chloro-4-floroaniline and 2-pyridinecarboxylidene-4 aminoantipyrine and their antimicrobial studies," The Korean Society of Mycology, vol. 40, no. 1, pp. 20-26, 2012.

[16] A. Prakash, M. P. Gangwar, and K. K. Singh, "Synthesis, spectroscopy and biological studies of nickel (II) complexes with tetradentate Schiff bases having $\mathrm{N}_{2} \mathrm{O}_{2}$ donor group," Journal of Developmental Biology and Tissue Engineering, vol. 3, no. 2, pp. 13-19, 2011.

[17] A. S. Munde, A. N. Jagdale, S. M. Jadhav, and T. K. Chondhekar, "Synthesis, characterization and thermal study of some transition metal complexes of an asymmetrical tetradentate Schiff base ligand," Journal of the Serbian Chemical Society, vol. 75, no. 3, pp. 349-359, 2010.

[18] U. K. Singh, S. N. Pandeya, S. K. Sethia et al., "Synthesis and biological evaluation of some sulfonamide Schiff's bases," International Journal of Pharmaceutical Sciences and Drug Research, vol. 2, no. 3, pp. 216-218, 2010.

[19] N. Raman, J. Dhaveethu Raja, and A. Sakthivel, "Synthesis, spectral characterization of Schiff base transition metal complexes: DNA cleavage and antimicrobial activity studies," Journal of Chemical Sciences, vol. 119, no. 4, pp. 303-310, 2007.

[20] V. Reddy, N. Patil, and S. D. Angadi, "Synthesis, characterization and antimicrobial activity of $\mathrm{Cu}(\mathrm{II}), \mathrm{Co}(\mathrm{II})$ and $\mathrm{Ni}(\mathrm{II})$ complexes with $\mathrm{O}, \mathrm{N}$, and $\mathrm{S}$ donor ligands," E-Journal of Chemistry, vol. 5, no. 3, pp. 577-583, 2008. 
[21] K. Nakamato, Infrared Spectra of Inorganic and Coordination Compounds, John Wiley, New York, NY, USA, 1970.

[22] S. Joshi, V. Pawar, and V. Uma, "Synthesis, characterization and biological studies of Schiff bases metal complexes Co (II), Zn (II), Ni (II), and Mn (II) derived from amoxicillin trihydrate with various aldehydes," International Journal of Pharma and Bio Sciences, vol. 2, no. 1, pp. 240-250, 2011.

[23] J. T. Makode and A. S. Aswar, "Synthesis, characterization, biological and thermal properties of some new Schiff base complexes derived from 2-hydroxy-5-chloroacetophenone and S-methyldithiocarbazate," Indian Journal of Chemistry A, vol. 43, no. 10, pp. 2120-2125, 2004.

[24] A. K. Mapari and K. V. Mangaonkar, "Synthesis, characterization and antimicrobial activity of mixed Schiff base ligand complexes of transition metal (II) ions," International Journal of ChemTech Research, vol. 3, no. 1, pp. 477-482, 2011.

[25] P. Venkatesh, "Synthesis, charecterisation and anti microbial activity of various Schiff base complex of zinc(II) and copper (II) ions," Asian Journal of Pharmaceutical and Health Sciences, vol. 1, pp. 8-11, 2011.

[26] M. Revanasiddappa, T. Suresh, S. Khasim, S. C. Raghavendray, C. Basavaraja, and S. D. Angadi, "Transition metal complexes of 1, 4(2'-hydroxyphenyl-1-yl) di-imino azine: synthesis, characterization and antimicrobial studies," E-Journal of Chemistry, vol. 5, no. 2, pp. 395-403, 2008. 

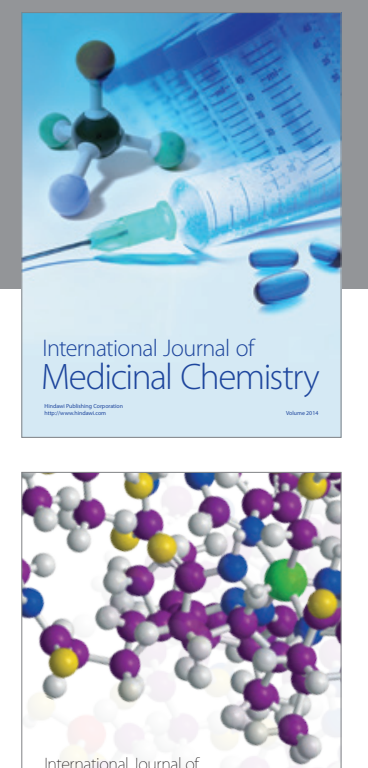

\section{Carbohydrate} Chemistry

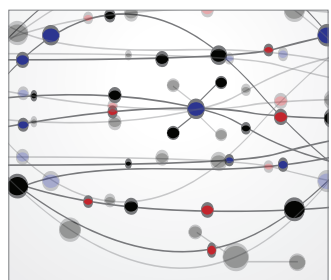

The Scientific World Journal
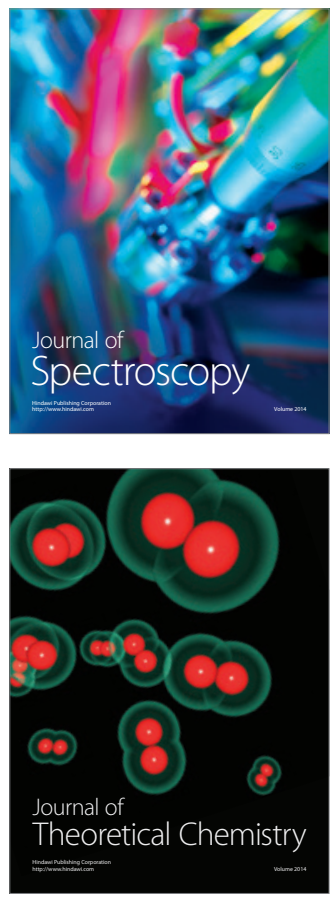
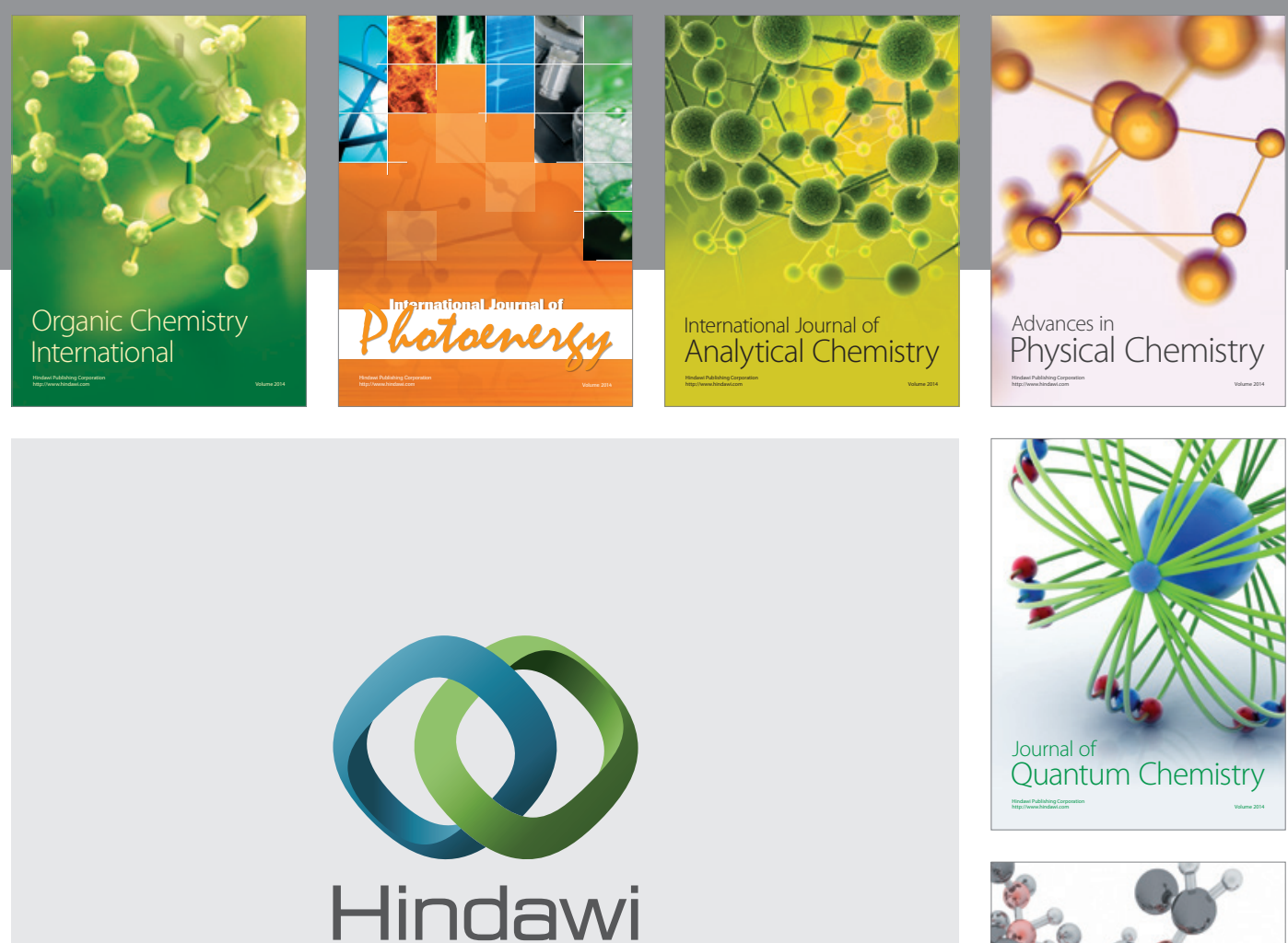

Submit your manuscripts at

http://www.hindawi.com

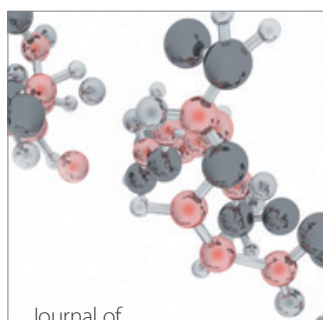

Analytical Methods

in Chemistry

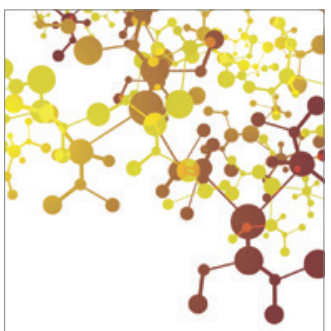

Journal of

Applied Chemistry

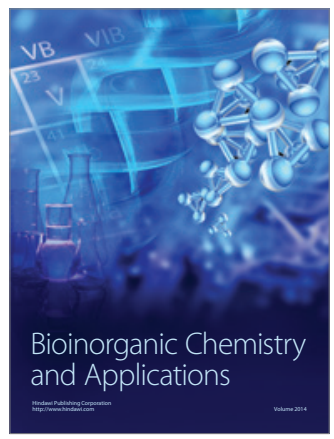

Inorganic Chemistry
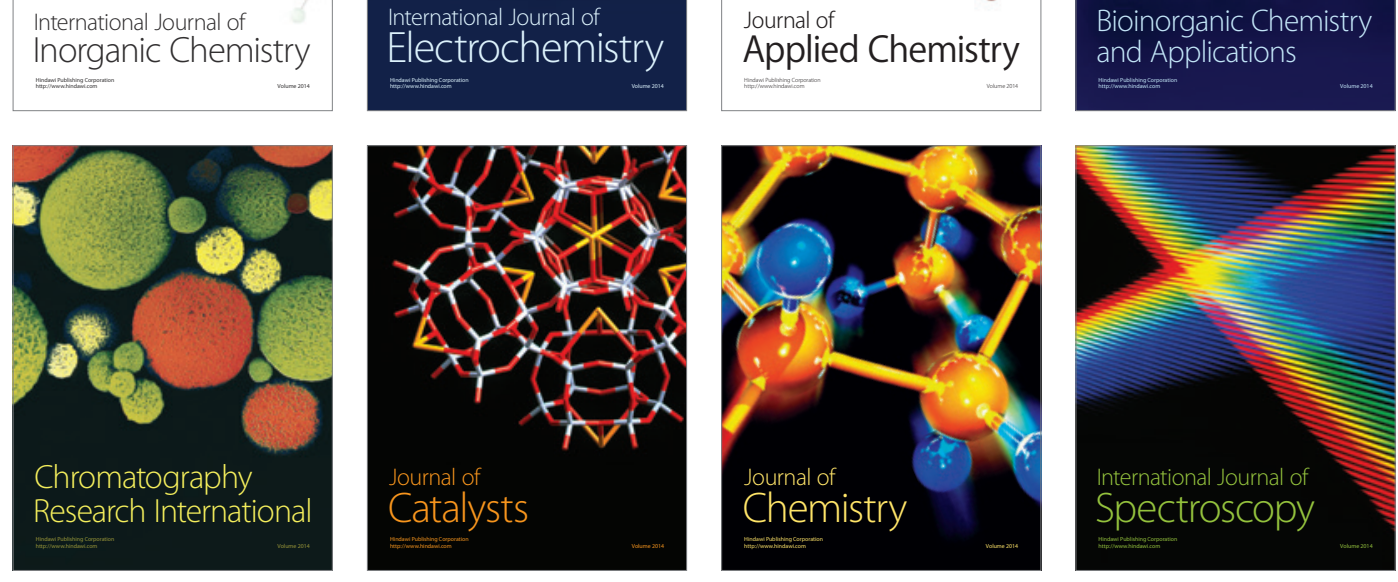